\title{
'NECESSITY' IN CRIMINAL AND MEDICAL JURISPRUDENCE: A COMPARISON OF COMMON LAW AND ISLAMIC LAW CONCEPTS
}

\author{
John Candlish ${ }^{*}$
}

\begin{abstract}
The jurisprudential concept of 'necessity,' which had its origins in the criminal aspects of both Common Law and Islamic Law, is becoming increasingly important in medical law, especially in relation to organ transplantation, therapeutic cloning, and in vitro fertilisation techniques. Criminal aspects remain closely related to the further concept of 'duress' (vitiation of free will) and civil/medical aspects to that of 'proportionality' (that the deviation from a norm must be related to the benefit obtained). This paper attempts to examine attitudes of Common Law and Islamic Law to these issues, after some preliminary remarks as to the difficulties and dangers of generalisation. However it may be confidently affirmed that the concepts of necessity and proportionality are well embedded in both systems. Notably also, in both systems there is an abhorrence of commercial transactions involving body parts. There are divergences however - Common Law, broadly, allows any sort of transplantation, for example for cosmetic
\end{abstract}

Professor, Kulliyyah of Allied Health Sciences, International Islamic University Malaysia. 
reasons, whereas as Islam regards this as essential only for the saving of life. In respect of therapeutic cloning there appears to be little divergence of views. In respect of in vitro fertilization, in all Common Law jurisdictions non-spousal sperm donors, anonymous or otherwise, are freely available, and may indeed be paid, whereas in Islam the spousal father must also be the biological father. It is a novelty of the modern world, however, that in almost all countries, even those with a majority Muslem population (like Malaysia) secular law allows freedom of choice so that involvement in these modern medical techniques devolves on personal morality.

\section{INTRODUCTION}

'Common Law' is usually taken to mean the set of rules originating in England, and to some extent in other countries of AngloSaxon provenance, and based upon the reasoning of judges, which in turn is heavily dependent upon decisions arrived at in previous decided court cases, that is, precedents. As might be expected, however, evolutionary pressures have generated considerable diversity among the various adherents. ${ }^{1}$ Islamic Law too consists of several schools ${ }^{2}$ and

1 Common Law jurisdictions may be listed, non-exhaustively, as England, Canada, Australia, New Zealand, U.S.A., India, Singapore, Malaysia, Ireland, and numerous smaller nations. Scotland's legal system was preserved as Roman-based after union with England but has both contributed to the Common Law precepts and been influenced by them. Recently there have been comments by senior judiciary in Malaysia that the country should move away from the Common Law system.

2 A study of the differing approaches of the various schools of Islamic law, including the Hanafī, Mãlikì, and Shäfi ' $\bar{l}$ would need a large book and probably a lifetime's study. I found helpful the brief Explanation/ summary of the various schools in a paper on website File:///A:/ Islamic\%20Law.htm. From the 'outsider's point of view, the difficulty is knowing who is a real authority on Islamic Law and who is not. I have for this paper consulted authors who are established faculty in 
among countries with an Islamic majority there is considerable variation in its application. ${ }^{3}$ Before entering my substantive theme it is apposite to make note of some general features of the two systems.

In common law litigation, quotations from previous judgements, especially those of the superior courts, are used extensively (thanks to formalized legal reporting) and applied to the facts of the extant case, with statute being interpreted as necessary. Islamic jurisprudence or fiqh looks to the writings of scholars, who are obliged to base their conclusions on the precepts of the Qur'ân, the Sunnah, and the Hadiths. This being the case, there is no a priori place for any civil/criminal dichotomy. To anybody schooled in the Common Law system, the lack of court-based precedents in Islamic Law texts (and indeed statute law as one understands it) is very striking. That is not to say, however, that there is no such thing as precedent in Islamic Law, and the gulf may not be as wide as it appears at first sight. In Common Law the judges and the drafters of statutes seldom have the last word, for hosts of practising and academic lawyers make haste to dispute or extend interpretation. Moreover common law judges are not above quoting from established works of reference by scholars rather than submit to a priori reasoning. ${ }^{4}$

recognized universities and books which appear to have the marks of scholarship about them.

According to the International Review of the Red Cross no. 858 (2005) (The Strength of Customary Law), 50 states in the world have a Moslem majority, of which 15 have proclaimed Islam as the state religion. Saudi Arabia for example would appear to operate Sharī'ah Law exclusively (but see text). Turkey on the other has been legally secular since the presidency of Kemal Ataturk. Although by the constitution Malaysia is an Islamic State, with a body of Sharī'ah law, any serious offence, and most of civil law, falls under the statutory and Common Law corpus, and the judges freely quote English, Canadian and Australian decisions (not so many from the US) without bothering to mention that they are extraterritorial. East Malaysia (Sarawak and Sabah) is different yet again. A separate paper if not a book would be necessary for full exploration of these matters.

Just to take one random example, in $R v$ Maloney [1985] A.C. 905 (HL), a murder case, Lord Bridge quoted from Archbold's Criminal Pleading Evidence and Practice, 1982. It is clear though that the judges prefer to quote from precedent, not textbooks. 
In addition, while keeping in mind that the basis of Islamic Law is divine revelation, one must remember that a principle source of Common Law is Judeo-Christian theology, as well as 'natural law,' which if not divine is at least founded on morality. ${ }^{5}$ In addition many crimes are ingrained in the conscience of humanity as a whole - murder, as opposed to sanctions against it, has never been legislated against as such - it has always been an abomination in both systems. Both systems, moreover, have perforce had to adapt to changing conditions. It would be idle to pretend that laws regulating motorised traffic specifically have a basis in the books of authority, sacred or otherwise. (Whether traffic laws are somehow derived from natural law fostering the common good in Common Law systems and equally, mașlahah or consideration of the public interest in Islamic Law, would need extensive argument in another paper). Nonetheless it seems that in Saudi Arabia, arguably the most Islamic of all states, for example, regulations regarding, let us say, the emplacement of fire extinguishers in cars, are dealt with by separate (secular) administrative tribunals. Common Law systems have not shown this flexibility - in England driving with under inflated tyres, is a criminal offence, like murder in that respect. In Malaysia too, for example, these major and minor transgressions are conflated and distanced from any aspects of Sharī‘ah Law.

After this short and no doubt superficial introduction, I go on to the more specific concepts of necessity and proportionality.

$5 \quad$ Natural law precepts are said to extend from as long ago as Magna Carta, still in force. There are many examples of the influence of religion per se in Common Law. There is even a view from Blackstone that much of English law is based on divine revelation. For many centuries non-Christians were not allowed to give evidence - evidently this affected mainly Jews. Until recently, or perhaps even today, an Anglican clergyman recites a prayer before the House of Lords delivers a judgement. Ecclesiastical courts still operate in limited spheres; for example they can debar a clergyman from his living - in that sense they more akin to a sort of private employment law; there is however appeal to secular courts. Whatever its origins, Common Law is now strictly secular. 


\section{ORIGINS OF NECESSITY IN CRIMINAL LAW: MURDER AND CANNIBALISM}

In an early US case the captain of a wrecked steamer found himself with eight seamen and 32 passengers in an overcrowded lifeboat. To prevent the boat swamping he threw 16 passengers overboard, ordering the crew not to separate husband and wife, nor sacrifice any woman (in other words only single men were drowned, that is, murdered). The judge observed that the crew should have been sacrificed first as they were bound to protect the passengers. ${ }^{6}$ The jury found the captain guilty but the sentence was light, a theme which will recur. Similarly, as a student of English criminal law, one learns at an early stage about necessity through the case of $R \mathrm{v}$ Dudley and Stevens. ${ }^{7}$ The two defendants were sailors aboard a yacht which was shipwrecked in 1884 . After sixteen days in the lifeboat the captain took a penknife and slit the jugular vein of the cabin boy, catching the blood in the chronometer case. This apparently kept the crew alive till they were picked up by a passing German vessel. In court the defendants adduced the 'law of the sea' (one facet of which was apparently that if there were two cabin boys, they should ideally be put in separate boats!) and it was said that the seafaring communities up and down the coasts had every sympathy with them. They were found guilty and sentenced to death but this was then commuted to six months hard labour. Thus the necessity defence was not accepted in respect of murder, although presumably it went to mitigation, via the commuted sentence. The interest in the present context is whether morality entered into the decision. In his judgement Lord Coleridge said: 'Though law and morality are not the same and though many things may be immoral which are not necessarily illegal, yet the absolute divorce of law from morality would be of fatal consequence....' He did not quote any religious text, however. Cases like this led to the creation of one of the fictitious legal persons which adorn Common Law, the 'person of reasonable fortitude.' That is, actions are judged against

\footnotetext{
$6 \quad$ US v Holmes, 26 Fed. Cas. 360 (1842).

7 Dudley and Stevens is discussed by Clarkson C.M.V. and Keating H.M. Criminal Law: Text and Materials, $2^{\text {nd }}$ ed. (1990), London, Sweet and Maxwell, p. 333. See also Simpson A.W.B. Cannibalism and the Common Law, University of Chicago Press, 1984.
} 
what a normal person, not a hero, would be reasonably expected to endure without breaking the law. ${ }^{8}$ The concept of the fictitious legal person is difficult to find in the Islamic law texts, but perhaps he appears in another guise, in relation to darürah. A hukum (rule) may be broken in the face of darürah, usually translated simply as 'necessity,' but undoubtedly, on a commonsense basis, reasonable fortitude is expected to be displayed before that drastic step is taken. Darürah is not extensively discussed even in the standard texts on Islamic jurisprudence such as that of Professor Mohamed Hashim Kamali ${ }^{9}$ but it is important for my purposes here to understand what the term means. On p. 424 of his learned treatment Dr. Hashim writes that haräm li-dhätih (that which is forbidden for its own sake) is not permissible save in cases of 'dire necessity' [my italics] which seems to imply that challenges less than dire should be countered with a degree of fortitude. Unfortunately, as mentioned above, one cannot readily compare the concepts of necessity and reasonable fortitude in Common Law with darürah by looking at respective case reports. However there is an interesting nexus to the above seafaring scenarios in that, according to Dr Sayed Sikandar Shah Haneef, in Islamic Law, duress is not a defence to murder. Punishment however is to be reduced from qișās to diyah - which is very reminiscent of the commutation of sentences in the English /US cases cited above. ${ }^{10}$ The same prohibition of killing for necessity holds, according to Dr Sayed, but some schools are said to accept this in a shipwreck situation (throwing some of the passengers overboard to save the rest). What is interesting is the apparent degree of unease or uncertainty in both systems as to the correct approach to defendants. According to Dr Sa 'îd Ramaḍān one cardinal principle is that what the Qur'ân and the Sunnah have prohibited become permissible whenever darürah arises, for example eating carrion or drinking alcohol to save life, but he does not mention murder. ${ }^{11}$ One can perceive the similarity of approach in the two systems.

\footnotetext{
$8 \quad R v$ Howe [1987] 1A.C. 417 (HL).

$9 \quad$ Mohammad Hashim Kamali. Principles of Islamic Jurisprudence. $2^{\text {nd }}$ edn. Islamic Texts Society, Cambridge, 2003.

10 Sayed Sikandar Shah Haneef. Homicide in Islam. A. Nordeen, Kuala Lumpur, 2000, p. 133. This is stated however not to be the view of the Hanafiyyah.

11 Sa î̀d Ramaḍann. Islamic Law. Muslim Youth Movement of Malaysia. Petaling Jaya, 1992, p. 71.
} 
Turning again to England and USA, more recent criminal cases in which a defence of necessity was pleaded have generally involved defendants who drove sick relatives to hospital while not being in possession of a driving licence or otherwise banned from driving. The leading case in England is $R v$ Martin $^{12}$ in which a wife threatened suicide if the defendant, who was disqualified from driving, did not drive her son to work. The judge laid out the principles of the necessity defence: 'The principles may be summarised thus: first, English law does, in extreme circumstances, recognise a defence of necessity. Most commonly this defence arises as duress, that is pressure on the accused will from the wrongful threats of another. Equally it can arise from other objective dangers threatening the accused or others. Arising thus it is conveniently called “duress of circumstances.” Secondly, the defence is available only if, from an objective standpoint, the accused can be said to be acting reasonably and proportionately [my italics] in order to avoid a threat of death or serious injury.' In the actual case the appeal was allowed because the above was not put to the jury.

In the case of US $v$ Randal $^{13}$ the defendant illegally consumed marijuana to relieve his glaucoma, and his defence of necessity was upheld on the basis of three maxims:

1 the defendant did not intentionally bring about the circumstances which precipitated the unlawful act.

2 the defendant could not accomplish the same object using a less offensive alternative.

3 the evil sought to be avoided was more heinous than the unlawful act perpetrated to avoid it.

Perhaps the principles are most clearly expressed in a Canadian case, Perka $v$ The Queen. ${ }^{14}$ The necessity defence is allowable under the following (conjoined) conditions:

1 the accused must be in imminent peril.

2 the accused must have no reasonable legal alternative.

$12 \quad$ [1989] 88 Cr. App. R. 343.

13 65923-75 D.C. Superior Court [1976].

$14 \quad$ [1984]2, S.C.R. 232. 
3 the harm inflicted by the accused must be proportional to the harm avoided by the accused.

The third point in the above two cases would seem to be restatement of the proportionality provision of Martin and so it would appear to be a well established concept - put as a question, does the violation of the norm bear a proportionate benefit to any of the parties involved? But again, referring to Perka, we see the persistent difficulty of jurisprudential interpretation. What do the words 'imminent,' 'reasonable' and 'proportional' actually mean? In the Common Law system one would say that guilt or innocence would turn on the facts of the case, in relation to the principles enunciated.

What of proportionality in Islamic Law? Dr Khaled Abou El Fadl writes that: 'There should be a proportional relationship between the social implications of a hadith and the burden of proof it should satisfy.' ${ }^{15}$ Dr Hashim Kamali writes, in the context of mașlahah: 'There must be a reasonable probability that the benefits of enacting a hukum... outweigh the harms that might accrue from it. ${ }^{16}$ This is clearly a proportionality principle, and no doubt other quotations could be garnered. Where the two systems seem to be at variance, however, is in the application of proportionality to sanctions. In the sense that amputation of a limb can be the penalty for theft (in some jurisdictions, indeed very few), Western writers fail to see proportionality. The retort by Islamic Law scholars in general is that such a severe punishment acts by its deterrent effect to diminish the rate of theft overall. One would need a statistical analysis of crime rates under some sort of controlled conditions to make an evaluation of this.

\section{MEDICAL LAW IN GENERAL}

Interesting as the criminal cases are, in this century medical law will be more important in adumbrating the principles of necessity and proportionality. The problem for the courts is that what might look like

\footnotetext{
$15 \quad$ Khaled Abou El Fadl. The Authoritative and Authoritarian in Islamic Discourses. Quill Publishers, Austin (1997).

$16 \quad$ See note 9.
} 
necessity to judge $\mathrm{A}$ and/or defendant $\mathrm{B}$ might be considered by judge $\mathrm{C}$ to be rather the luxury of choice in terms of inflated expectations. The 62 year old woman who in England who is at this moment expecting a child, thanks to massive endocrine manipulation, can be regarded as either fulfilling her biological imperative/necessity, for motherhood, or alternatively exerting an unnatural greed at the expense both of healthcare resources and the psychological state and well being of the desired child. In the Common Law world such expectations can be legally fulfilled. Can the adoption of children by same sex couples be regarded as a necessity? No norm can be adduced for an answer. Recently in England and some states of the USA same sex marriages have been legalised. They have been condoned on the basis of the necessity of safeguarding the financial status of a partner in a long-standing relationship. These matters remain controversial, and if not regarded by much of the population in the West as an authorisation of sin, they are widely regarded with distaste. After reading the literature it is difficult, within the general tenor of Islamic law, to see any of this being tolerated at any time.

In the context of health matters as such Islamic Law appears to have no difficulty with the concept of necessity, for example in allowing a female patient to be examined by a male doctor, in that a priori, in a vast body of Islamic thought (I take this as so well-known as not to require citation) an unrelated male is permitted to see only the face and hands of another woman. The male doctor, obviously, might be the only help available or the only one who can exercise a particular skill. Reading the various commentaries, it appears clear that in the twentieth century there were a number of developments which called for ijtihäd, or new

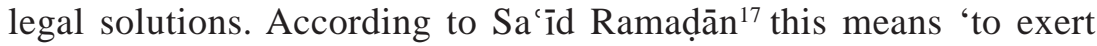
oneself.' Consequently Islamic jurisprudentialists adopted what is called maslahah, (welfare, benefit, utility) coupled to darürah in their approach to novelties, including those in the medical field. On the other hand other scholars regard public interest, or maslahah/darūrah, as a source of law to be more or less reducing the position of Divine Law to that of man-made law, that is, completely unacceptable. 


\title{
SAVING AND PRESERVATION OF LIFE
}

It is hoary old oft-quoted principle of Common Law that one is under no legal obligation to rescue someone who (for example) is drowning, even if one is put in no danger by attempting this. The principle is said to be that freedom is only to be restricted when it is necessary to prevent persons doing harm to others - otherwise individual liberty and autonomy prevail. ${ }^{18}$ Thus there is no obligation to prevent a person committing suicide. It is a criminal offence to assist, however. In the Common Law system, there are no circumstances wherein a life may be actively terminated. This is not to say that an individual may not be allowed to die. In Re J (1990) a case before the English Court of Appeal, the court had to consider a premature baby born with very severe defects, including loss of brain tissue, quadriplegia, and blindness and deafness. He could experience pain, however. The medical staff wished for a ruling on whether they should reventilate him if he had a respiratory collapse or, in effect, let him die should this happen. At of first instance the judge had stated the latter to be permissible, but the judgement was opposed by the Official Solicitor (whose function is to safeguard in every possible way a ward of court). The Master of the Rolls (the head of the civil justice system) said:

\begin{abstract}
'What is in issue is ...not a right to impose death, but a right to choose a course of action which will fail to avert death...' and '...there is a balancing exercise to be performed in assessing the course to be adopted in the best interests of the child. ${ }^{19}$
\end{abstract}

There was a declaratory judgement in effect allowing the baby to die. Whether one agrees, or not, with the decision, the balancing, or proportionality principle is evident. In Airedale NHS v Bland (1993 $)^{20}$ the hospital applied to the court for permission to switch off the life support system of a young man who had been rendered into a persistent

\footnotetext{
18 There is a discussion of killing by omission in Clarkson and Keating note 7, p. 137.

19 [1991] Fam 33.

20 1All E.R. 858 HL.
} 
vegetative state by being crushed at the Hillsborough football disaster. The jurisprudence was enunciated by the Court of Appeal and the House of Lords gave this its imprimatur. The various rationales, over three courts, for termination of the treatment, are complicated, but in the end boiled down to the question: was the continuance of the life-support proportional to the benefit to the patient? Clearly, the decision was that it was not. In $\operatorname{Re} S$ a woman in labour refused to have a caesarian because she said that God would provide for both herself and the baby. The baby was on a transverse lie, and medical opinion was that unless the procedure was performed the baby would die and there was a palpable risk to the mother also. ${ }^{21}$ The judge allowed the caesarian to go ahead against the wishes of $\mathrm{S}$, thereupon violating the hallowed principle that a conscious adult individual of sound mind is entirely autonomous in deciding the disposal of her own body. The foetus died and the mother survived. (There was a happy ending of sorts in that the mother, who had two other children, came to the conclusion that the judge in any case probably represented divine will). The judge was clearly balancing the autonomy principle against the interests of the mother and the foetus.

According to Dr Sayed Sikandar, 'Human life can be taken away in a truthful cause. In respect of euthanasia, there is no obligation to keep such a person alive in such a manner. But to take the life of a person, out of mercy or compassion, to end his sufferings is undoubtedly harām in Islam. ${ }^{22}$ This appears to be almost exactly the position of the English court in In re J. It is difficult to find parallels to the circumstances in Islamic Law. In a country like Malaysia these matters are taken out of the hands of the Sharī'ah courts, although it is possible that the secular courts would take note of religious views. A fully Islamic country like Saudi Arabia, as far as I know, does not furnish reports on such matters, interesting as those would be.

\section{ORGAN TRANSPLANTATION}

The great concordance between the two systems, and others, is the prohibition of the commercial traffic in bodily organs (in Malaysia by

\begin{tabular}{ll}
\hline 21 & [1992] 3 W L R 806. \\
22 & See note 10.
\end{tabular}


an amendment to the Human Tissue Act of 1974). In Common Law countries the abhorrence must have its origins ultimately in, if not religion, ancient perceptions of morality. (See Lord Coleridge's speech above). In Islam too there is the precept that the body belongs to God and that to trade parts of it is anathema.

In respect of organ donation, the meaning and definition of death (thus the meaning of 'brain dead') is important. Kidney donations to relatives are practiced all over the Islamic world, but the removal of organs from the dead for transplantation seems to be causing more difficulty. This is because of the concept of hurma or sanctity of the human body. Some authorities attach such great significance to this that they disapprove of corneal removal, for example, from the dead. Others argue from traditional cases which allow of necessity, and this would appear to be the attitude of most of the Islamic authorities in countries like Malaysia and Singapore. Moreover postmortems are allowed in Islamic law - but only in the interests of detecting the cause of death, investigating criminality, and for the education of medical students necessity once again. ${ }^{23}$ This aspect of necessity is indirectly related to the saving of lives, like the consumption of carrion or parts of the dead human body.

All the same, the object of transplantation must be to save life, not to prolong it or improve it, to qualify under darürah. (Artificially prolonging life appears to be forbidden under the doctrine that the inevitability of death must be recognised). Moreover the concept of darürah cannot, it seems, be carried over to organ or tissue banks.

\section{THERAPEUTIC CLONING}

Therapeutic cloning was given the go ahead at an important conference of the Islamic Organisation for Medical Sciences held in Cairo in December 2004, although apparently the motion allowing it was not unanimous. Dr Abdul Aziz Sachedina states that human embryos lack the same sanctity in Islam as they do in Christianity, and are not

$23 \quad$ Krawietz B. Darürah in modern Islamic Law: the case of organ transplantation. In: Islamic Law, Gleave R. and Kermeli E, eds. I.B. Taurus, London, 2001, p. 79. 
regarded as people in any sense. ${ }^{24}$ It is the opinion of Professor Omar Kasule that the use of zygotes for medical research could be allowed under the law that states that necessities permit the prohibited. ${ }^{25}$

Therapeutic cloning is limited in USA apparently due to a predominant belief that a human being is created at conception. The restrictions were however advanced by president Bush as executive order rather than by the courts. In the United Kingdom there is no such restrictive view and procedures are readily licenced by the Human Fertilisation and Embryology Authority. Singapore is reputed to possess the most enabling of all administrations in respect of therapeutic cloning as well as stem cell research and has even attracted eminent scientists from the West to advance its ambitions in this direction. The Islamic authorities therein seem not to have objected.

\section{IN VITRO FERTILISATION}

In vitro fertilization, sometimes quaintly latinised as fecundatio $a b$ extra (and in times when reproductive technology was slightly less advanced, to 'artificial insemination by donor' or AID) presents no difficulties for secularized Common Law as such, disputes centering round ownership rather than morality. (Thus, does the property in the sperm of a former partner vest with him, or can the other partner use it for fertilisation against his wishes? These complexities are still being worked out). Islamic Law differs radically, however. According to Dr Gamal Serour, writing in the medical journal Lancet, ${ }^{26}$ the social father or mother of a child must be the genetic father or mother, so sperm and egg donation, embryo donation and surrogacy are unacceptable in Islam. Professor Kasule agrees. Necessity has strict limits, as might be anticipated in the context of Islamic ethics per se. Logically, the same precepts must be applied AID. As I was completing this paper, there came a note of the

\footnotetext{
$24 \quad$ File:///A:Muslim\%20states\%20urged\%20to\%20back\%20therapeutic accessed 24/5/06.

25 Kasule O.H. Derivation of legal rulings on in vitro fertilization from the purposes of the law. International Medical Journal 4, 54 (2005). Gamal Serour. An enlightening guide to the health-care needs of Muslims. Lancet 358, 159 (2001).
} 
following legal imbroglio with artificial insemination as a backdrop. It is from the Court of Appeal (Civil Division) in England, and I quote:

' $\mathrm{J}$ [the appellant] had in law been a female when he purportedly married the first respondent (C) who was E's mother. $\mathrm{J}$ and $\mathrm{C}$ had lived together as husband and wife although $C$ had not been aware of J's sex [!]. E had been conceived by means of artificial insemination by donor. In due course the relationship between $\mathrm{J}$ and $\mathrm{C}$ broke down and their marriage was declared void. ${ }^{27}$

$\mathrm{J}$ was appealing against the decision of the trial court that he (she?) was not child's father. (As an aside, how could this absurdity reach the Court of Appeal? Clearly the 'marriage' was void, not only because the parties were of the same sex but also for non-consumation. How could a court even entertain an application by a woman claiming to be a 'father'?) Nonetheless, having had the matter brought to its notice, the Court of Appeal had no hesitation in dismissing the fatherhood claim; it opined that the real issue was the welfare of the child $\mathrm{E}$, and how she was to be informed about her origin. I have no parallel case to go on, but one would guess that a Sharī'ah court would deal with matter in much the same way, if perhaps more summarily.

\section{CONCLUSION}

As would be expected, there are similarities and differences between Common Law and Islamic Law attitudes to the matters which have been discussed above. Notably, though, both have an inherent flexibility to deal with modern scientific and social changes. Necessity and proportionality are useful bases for reasoning in both. Some commentators have argued that the flexibility of Islamic law has been most apparent in international law (not however the subject of this paper), in respect of Article 6(2) of the International Covenant on Civil and

27 http://www.telegraph.co.uk/news/main.jhtml?xmal=/news/lawreorts/ lawreps05.xml\&sShe... Accessed 1/6/06. 
Political Rights for example, if not in respect of punishments. ${ }^{28}$ The salutary aspect of many modern states with an Islamic majority is that Sharī' ah law is largely overridden by statute and/or Common Law, secular law at any rate, which can be roughly equated to the government. As Dr Hashim Kamali has written 'The history of Islamic jurisprudence is marred by a polarization of interests between the government and the ulema. The ulema's disaffection with the government did not encourage the latter's participation and involvement in the development of juristic thought and institutions. ${ }^{29}$ The religious authorities in most Common Law countries became accustomed to being ignored a long time ago.

$28 \quad$ Shabas W. Islam and the death penalty. William and Mary Bill of Rights Journal 9, 223 (2000).

$29 \quad$ See note 9. 